EREM 74/2

Journal of Environmental Research, Engineering and Management Vol. 74 / No. 2 / 2018 pp. $52-57$ DOI 10.5755/j01.erem.74.2.20537 (c) Kaunas University of Technology

\section{Computer Aided Simulation of the Pyrolysis of Waste Lubricating Oil Using Aspen Hysys}

Received 2017/12

Accepted after revision 2018/02

\title{
Computer Aided Simulation of the Pyrolysis of Waste Lubricating Oil Using Aspen Hysys
}

\author{
A. G. Adeniyi, L.T. Adewoye, J. 0. Ighalo \\ Chemical Engineering Department, University of Ilorin, Nigeria
}

Corresponding author: A. G. Adeniyi

Chemical Engineering Department, University of Ilorin, Nigeria

The pyrolysis of waste lubricating oil is an exciting technique of converting waste materials into useful products by thermal decomposition at elevated temperature under inert conditions. Aspen HYSYS 2006 was used to develop a computational steady-state model to simulate the pyrolysis of waste lubricating oil and analyze its performance. The Peng-Robinson fluid package was used for the simulation. The pyrolysis reaction was modeled by a combination of the yield-shift reactor and the Gibbs reactor. At a pyrolysis temperature of $350^{\circ} \mathrm{C}$ and atmospheric pressure, $77.92 \%$ liquid yield was obtained. The product composition and chemical properties of the pyrolysis oil were also predicted by the simulation and are in good agreement with experimental results. This has proved that pyrolysis of Waste lubricating oil can give a very good yield of liquid product and is a viable recycling technique.

Keywords: Pyrolysis, Simulation, Waste Lubricating oil, Aspen Hysys.

\section{Introduction}

Due to the growth in the use of internal combustion engines over the years, there has been a similar rise in the demand and use of lubricating oils. Lubricating oils are widely used to reduce friction and wear because they serve as a material film between metallic surfaces in contact (Rosli, Yee, \& Tea, 2002). Lubricating oil is one of the heavier fractions of crude oil distillation.
Commercial lubricating oils are obtained by blending different viscosity-based oils with suitable proportions of additives (N B Selukar \& S M Wagh, 2014).

The most important property of lubricating oil is viscosity. Through the use of Lubricating oils, they lose this property, become contaminated and at some point, become ineffective (Sharaf, Mishra, \& Sharma, 
2013). In any system where lubricating oil is used, waste lubricating oil (WLO) is consequently generated. The production of waste automotive engine oil is estimated at 24 million tons each year throughout the world (Nasim, Sohail, Ravindra, \& Lotia, 2014). It is currently posing a serious treatment and disposal problem in the modern society.

Numerous techniques are currently available for the disposal and/or recycle of waste lubricating oils. The preferred disposal options in most nations are incineration, sludge disposal and combustion for energy recovery. Recycling options include vacuum distillation and hydrotreatment. However, these routes are becoming increasingly unfavorable as there are growing concerns over environmental pollution, and additional cost (Nasim et al., 2014).

Interest in waste recycling is steadily growing, and alternative methods are being explored with the aim of recovering both the energetic and chemical value of the waste oil. Pyrolysis has shown great promise as an economic and eco-friendly disposal method for waste in general and waste oil in particular. Pyrolysis is the thermal cracking of waste materials at elevated temperatures under inert conditions. The products are char, non-condensable gases and oil (Di Blasi, 1994).

Pyrolysis oil consists of a wide range of hydrocarbons and the component distribution in the oil is dependent on the raw material used for pyrolysis. It exhibits diesel range properties and it has been shown to run smoothly on diesel engines (Wongkhorsub \& Chindaprasert, 2013a). The Char is essentially carbon black and it is a raw material for activated carbon production. The gaseous product consists mainly of non-condensable gases. It is also combustible and can be harnessed to serve as a substitute for synthesis gas.

Generally, pyrolysis involves numerous complex chemical reactions which usually end up in a large number of intermediates and end products. To devise an exact reaction mechanism and kinetic model for pyrolysis is extremely difficult. Hence, pyrolysis models are prepared on the basis of visible kinetics (Prakash \& Karunanithi, 2008).

The kinetic modeling of pyrolysis paved the way for researchers to propose different reaction mechanisms; this has subsequently developed a lengthy history (Srivastava, Sushil, \& Jalan, 1995), (Di Blasi, 1994), (Srivastava, Sushil, \& Jalan, 1996). Even today, it is difficult to develop a precise kinetic model taking into account all the parameters concerned (Prakash \& Karunanithi, 2008).

Simulators mimic the behavior of a system and help to predict the effect of various applied changes (Licker, 2003). The simulation of the process was performed using Aspen HYSYS 2006. Aspen HYSYS along with other process simulators such as Aspen PLUS, CHEMCAD and PROSIM facilitate the design, sizing, simulation and optimization of a chemical and/or a refinery plant and the required equipment. ASPEN HYSYS and ASPEN PLUS are extensively used in the industries since they help chemical engineers in two major fields: Design and Operation (Ordouei, 2009).

\section{Methodology}

\section{Fluid Package and components}

The Peng-Robinson (PR) property package was used in the simulation. The lubricating oil is approximated by cloning a base hydrocarbon compound to a hypothetical compound which then allows for the manipulation of certain known properties of the liquid to mimic those of lubricating oil. The properties of used lubricating oils used in the computation are presented in Table 1.

\section{Table1}

Properties of used lubricating oils

\begin{tabular}{|c|c|c}
\hline \multicolumn{1}{c|}{ Properties } & Values & \multicolumn{1}{c}{ Source } \\
\hline 1 & 2 & 3 \\
\hline Specific gravity & 0.91 & Yee et al., 2002 \\
\hline Volume \% of water & 12.3 & Yee et al., 2002 \\
\hline Base component & $\mathrm{nC20}$ & Assumed \\
\hline
\end{tabular}

These set of data serves as the basis given to Aspen HYSYS to estimate all other physicochemical properties of the hypothetical component. Hydrocarbons from $\mathrm{C}_{1}$ to $\mathrm{C}_{29}$ were included in the component list. The software also computed the product distribution of these components in the pyrolysis oil and non-condensable gas. 


\section{Simulation Environment}

Several reactor blocks were incorporated to completely model the pyrolysis reaction, as presented in Figure 1.

Based on the experimental design by Wisa Manasomboonphan and Suwannee Junyapoon (2012), the water in the used lubricating oil is set to dry by heating the oil to about $110^{\circ} \mathrm{C}$ and entraining the water vapor with a purge gas stream of Nitrogen. The Pyrolysis reactor is modeled by a combination of the yield-shift and Gibbs reactor. The yield shift reactor carries out the conversion of Non-conventional/hypothetical materials (used lube oil) to conventional components while the Gibbs reactor then does the calculation of the phase and chemical equilibria thereby predicting the product composition (via minimization of Gibbs free energy). The feed of dry lube oil goes into the yield-shift reactor and final products are retrieved in two streams at the Gibbs reactor (kept at a temperature of $350^{\circ} \mathrm{C}$ ).

The bottom stream is composed of elemental carbon which is the char. The vapor will be condensed to obtain the other two products. As designed by Wisa Manasomboonphan and Suwannee Junyapoon (2012), a triple condensation system is implemented to separate the pyrolysis oil from the non-condensable gases. The three condensers were included to run at temperatures $65^{\circ} \mathrm{C}, 25^{\circ} \mathrm{C}$ and $25^{\circ} \mathrm{C}$ respectively. All condensate streams are subsequently mixed together to get a single stream of liquid product. Synthesis gas is gotten as the final over-head product of the condensation system.

\section{Results and discussion}

At the end of pyrolysis, with the feed rate of $10 \mathrm{~kg} / \mathrm{hr}$, pyrolysis temperature, $350^{\circ} \mathrm{C}$ and reactor heating rate of $1.684 \mathrm{KW}$, the results of the simulation obtained are presented in Table 2

\section{Table 2}

Simulated Values of Pyrolysed Products

\begin{tabular}{l|l}
\hline \multicolumn{1}{c|}{ Product } & \multicolumn{1}{c}{ Yield $(8.65 \mathrm{~kg} / \mathrm{hr})$} \\
\hline \multicolumn{1}{c|}{1} & \multicolumn{1}{c}{2} \\
\hline Pyrolysis oil & $6.740 \mathrm{~kg} / \mathrm{hr}(77.92 \%)$ \\
\hline Char & $0.2759 \mathrm{~kg} / \mathrm{hr}(3.19 \%)$ \\
\hline Synthesis Gas & $1.651 \mathrm{~kg} / \mathrm{hr}(19.09 \%)$ \\
\hline
\end{tabular}

Fig. 1

The process flow diagram of the simulation

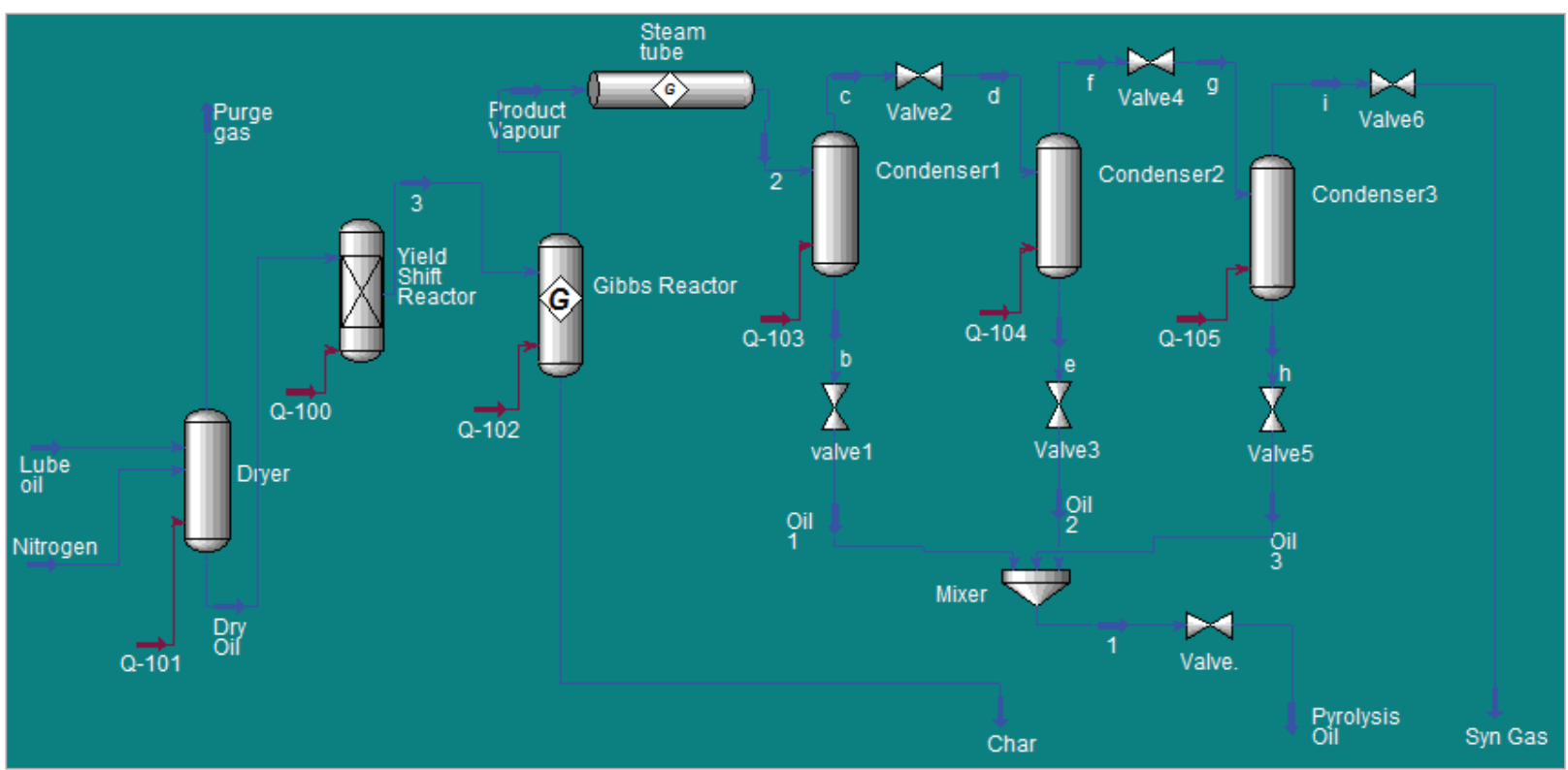


Table 2 is in agreement with Wisa Manasomboonphan \& Suwannee Junyapoon, 2012 who obtained a greater than $50 \mathrm{wt} \%$ yield of pyrolysis oil at a temperature of $350^{\circ} \mathrm{C}$. The amount of char predicted by the simulation is quite small because the lubricating oil was originally obtained from a hydrocarbon hence is traditionally expected to produce far less char than conventional biomass that consists of numerous other non-hydrocarbon compounds. The profile of the is presented in Figure 2, this contains basically elemental carbon

The simulated hydrocarbon gases are presented in Figure 3, they are the major components of the synthesis gas obtained. Most significant is the proportion of methane $(64 \mathrm{~mol} \%)$ in the gas. However, traces of $\mathrm{C}_{6}(\leq 1.6 \mathrm{~mol} \%)$ and $\mathrm{C}_{7}$ $(\leq 0.8 \mathrm{~mol} \%)$ vapors do exist in the gas.

The simulated pyrolysed oil (liquid fraction) showed a wide range of hydrocarbon components. However, a significant proportion is accounted by $\mathrm{C}_{21}$ to $\mathrm{C}_{29}$ range hydrocarbons. This is in line with results obtained by Wisa Manasomboonphan and Suwannee Junyapoon (2012).

The properties of the oil obtained are presented in Figure.

The chemical properties of the oil are very important as it is a major pointer to the usability and functionality of the product. Essentially, pyrolysis oil is used as a fuel in diesel engines. N. B Selukar and S. M Wagh (2014) obtained and characterised liquid products from lube oil pyrolysis at three different temperatures.. The density of the simulation liquid product (797.1 $\mathrm{kg} / \mathrm{m}^{3}$ Std. Ideal Liq.) is lower than those obtained by N. B Selukar and S. M Wagh (2014) (between $833 \mathrm{~kg} / \mathrm{m}^{3}$ and $861 \mathrm{~kg} / \mathrm{m}^{3}$ ). The viscosity is however consistent with experimental results, especially those by N. B Selukar and S. M Wagh (2014) and Wongkhorsub and Chindaprasert (2013b). Also, a key index of its viability as a fuel for combustion engines is the heating value. A heating value of about 43,000 $\mathrm{KJ} / \mathrm{Kg}$ is valid as it falls well within the range for most other pyrolysis oils both from different sources, and different experimental set-ups.
Fig. 2

Composition of the Simulated Char

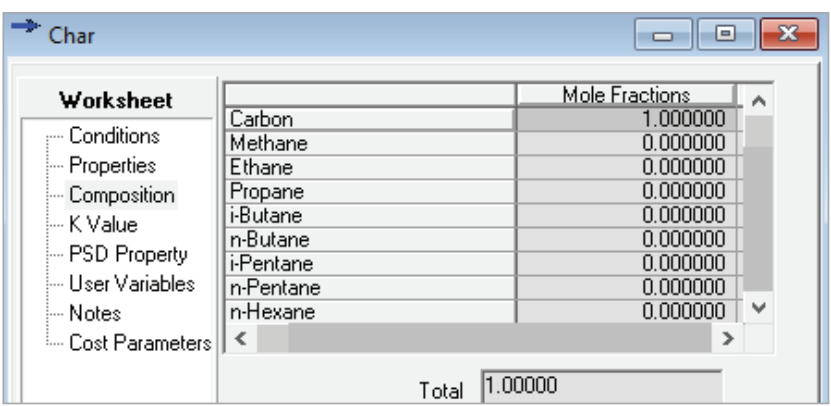

Fig. 3

Composition of the Simulated Hydrocarbon gases

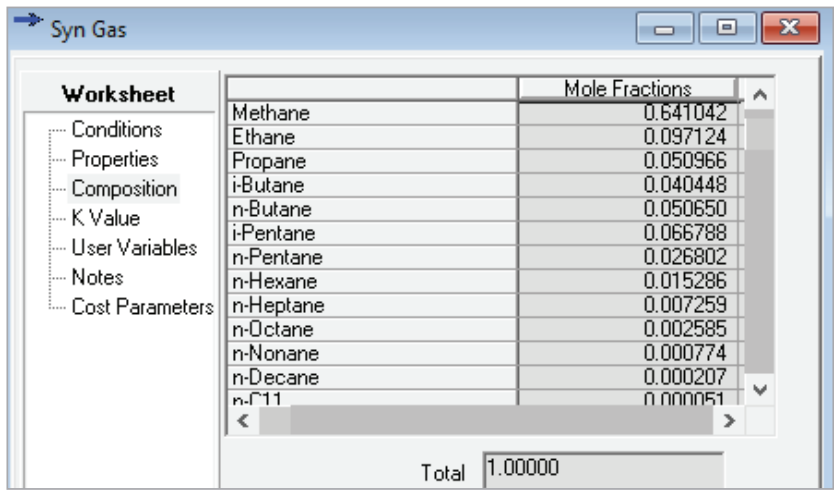

Fig. 4

Composition and properties of the oil

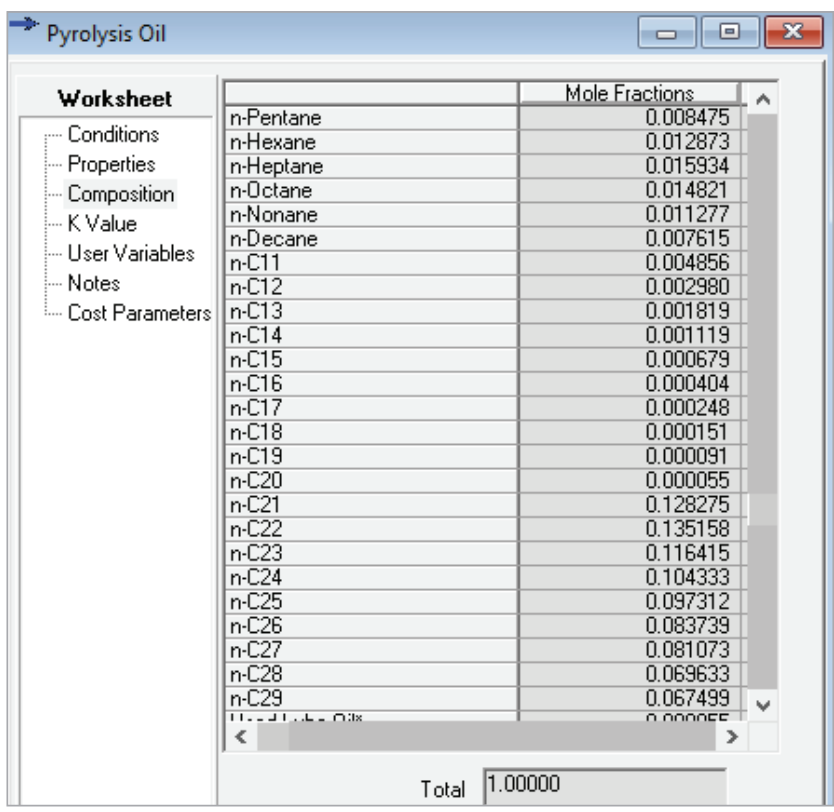


Fig. 5

Properties of the simulated oil

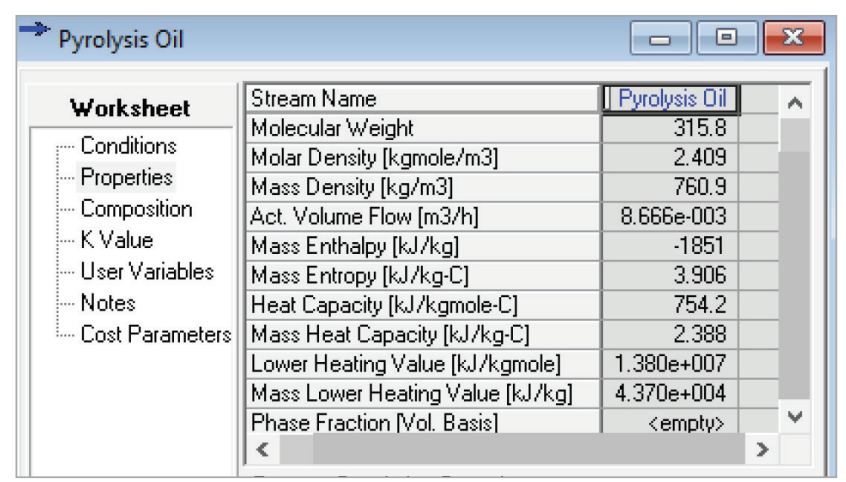

\begin{tabular}{|c|c|c|c|}
\hline$\rightarrow$ Pyrolysis Oil & & 口回 & $x$ \\
\hline & Avg. Liq. Density [kgmole/m3] & 2.524 & A \\
\hline Worksheet & Specific Heat $[\mathrm{kJ} / \mathrm{kgmole}-\mathrm{C}]$ & 754.2 & \\
\hline Conditions & Std. Gas Flow [STD_m3/h] & 0.4936 & \\
\hline Properties & Std. Ideal Liq. Mass Density [kg/m3] & 797.1 & \\
\hline Composition & Act. Liq. Flow [m3/s] & $2.407 \mathrm{e}-006$ & \\
\hline KValue & ZFactor & $1.496 \mathrm{e}-002$ & \\
\hline User Variables & Watson K & 13.15 & \\
\hline Notes & User Property & $\langle e m p t y\rangle$ & \\
\hline Cost Parameters & Partial Pressure of $\mathrm{H} 2 \mathrm{~S}$ [kPa] & 0.0000 & \\
\hline & {$[\mathrm{C} /([\mathrm{Cp} \cdot \mathrm{R}]$} & 1.011 & \\
\hline & $\mathrm{Cp} / \mathrm{Cv}$ & 1.188 & \\
\hline & Heat of Vap. [kJ/kgmole] & $3.715 e+005$ & \\
\hline & Kinematic Viscosity [cSt] & 3.913 & \\
\hline & Liq. Mass Density [Std. Cond] $[\mathrm{kg} / \mathrm{m} 3$ ] & 794.7 & $\checkmark$ \\
\hline
\end{tabular}

\section{Conclusions}

Aspen HYSYS 2006 was used to simulate the pyrolysis of waste lubricating oil. The pyrolysis reaction can be modeled by a combination of the yield-shift reactor and the Gibbs reactor. The yield shift reactor carries out the Conversion of Non-conventional/hypothetical materials (used lube oil) to conventional components. The Gibbs reactor then does the calculation of the phase and chemical equilibria thereby predicting the product composition (via minimization of Gibbs free energy).
At a feed rate of $10 \mathrm{~kg} / \mathrm{hr}$, a pyrolysis temperature of $350^{\circ} \mathrm{C}$ and at atmospheric pressure, $77.92 \%$ liquid yield was obtained. This has proved that pyrolysis of Waste lubricating oil can give a very good yield of liquid product and is a viable recycling technique. The product composition and chemical properties of the products from the simulation are in good agreement with experimental results.

\section{References}

Di Blasi, C. (1994). On The Influence of Physical Processes on the Transient Pyrolysis of Cellulosic Samples. Paper presented at the FIRE SAFETY SCIENCE-PROCEEDINGS OF THE FOURTH INTERNATIONAL SYMPOSIUM. https://doi.org/10.3801/IAFSS. FSS.4-229

Gavin, W., Stuart, D., \& Emilio, R. (2016). Modeling the impact of biomass particle residence time on fast pyrolysis yield and composition. Paper presented at the AIChE Annual Meeting in San Francisco, San Francisco.

Jones, J. R. (2011). MECHANISMS OF PYROLYSIS? : New Zealand Biochar research center.

Licker, D. M. (2003). Dictionary of Engineering. Chicago: McGraw Hill Publishers.

Manasomboonphan, W., \& Junyapoon, S. (2012). Production of liquid fuels from waste lube oils used by pyrolysis process. Paper presented at the 2 nd International Conference on Biomedical Engineering and Technology, IPCBEE.

Manasomboonphan, W., \& Junyapoon, S. (2012). Production of Liquid Fuels from Waste Lube Oils Used by Pyrolysis process. Paper presented at the 2nd International Conference on Biomedical Engineering and Technology, Singapore.

Nasim, M. N., Sohail, M. P., Ravindra, B. Y., \& Lotia, V. N. (2014). Recycling waste automotive engine oil as alternative fuel for diesel engines; A review. Journal of Mechanical and Civil Engineering (IOSR-JMCE), 46-50.

Ordouei, H. M. (2009). Computer Aided Simulation and Process Design of a Hydrogenation Plant Using Aspen HYSYS 2006. Waterloo, Ontario, Canada.

Prakash, N., \& Karunanithi, T. (2008). Kinetic Modeling in Biomass Pyrolysis - A Review. Journal of Applied Sciences Research, 4(12), 1627-1636.

Rosli, M., Yee, F. C., \& Tea, S. S. (2002). Modeling and Simulation of Used Lubricant Oil Re-refining Process. Paper presented at the 2nd World Engineering Congress, Sarawak, Malaysia. 
Selukar, N. B., \& Wagh, S. M. (2014). Gasoline and Diesel Synthesis from Waste Lubricating Oil: A Kinetic Approach. IOSR Journal of Applied Chemistry (IOSR-JAC), 22-25.

Selukar, N. B., \& Wagh, S. M. (2014). Gasoline and Diesel Synthesis from Waste Lubricating Oil: A Kinetic Approach. Journal of Applied Chemistry (IOSR-JAC), 22-25.

Sharaf, J., Mishra, B., \& Sharma, R. B. (2013). Production of gasoline-like fuel obtained from waste lubrication oil and its physicochemical properties. International Journal of Engineering Research and Applications (IJERA), 3(3), 113-118.

Srivastava, V. K., Sushil, \& Jalan, K. R. (1995). Prediction fo concentration in the pyrolysis of biomass material. Energy conversion management, 37(4), 473-483. https://doi. org/10.1016/0196-8904(95)00200-6
Srivastava, V. K., Sushil, \& Jalan, K. R. (1996). Development of Mathematical Model for the prediction of concentration in the pyrolysis of biomass material. Indian journal of chemical technology, 3, 71-76.

Wongkhorsub, C., \& Chindaprasert, N. (2013a). A Comparison of the Use of Pyrolysis Oils in Diesel Engine. Energy and Power Engineering, 5, 350-355. https://doi.org/10.4236/ epe.2013.54B068

Wongkhorsub, C., \& Chindaprasert, N. (2013b). A comparison of the use of pyrolysis oils in diesel engine. Energy and Power Engineering, 5(04), 350. https://doi.org/10.4236/epe.2013.54B068 Yee, C. F., Yunus, M. R., \& Sin, T. S. (2002). Modeling and Simulation of Used Lubricant Oil Re-refining Process. Paper presented at the 2nd World Engineering Congress, Sarawak, Malaysia.

\section{Panaudotos alyvos pirolizès kompiuterizuotas modeliavimas naudojant "Aspen Hysys"}

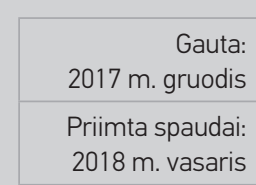

\section{A. G. Adeniyi, L.T. Adewoye, J.0. Ighalo}

Chemijos inžinerijos katedra, Ilorin universitetas, Nigerija

Vykdant panaudotos alyvos pirolizę yra būdas atliekas paversti naudingais produktais, termiškai skaidant esant aukštai temperatūrai inertinèmis sąlygomis. Aspen HYSYS 2006 buvo naudojama sukurti skaičiavimo stacionariosios būklès modeli, kuris imituotų panaudotos alyvos atliekų pirolizę ir analizuotu jos veikimą. Modeliavimo metu buvo naudojamas „Peng-Robinson“ skysčio paketas. Pirolizès reakcija buvo modeliuojama pasiskirstymo reaktoriaus ir Gibso reaktoriaus deriniu. Esant pirolizès temperatūrai $35000{ }^{\circ} \mathrm{C}$ ir atmosferos slegiui, buvo gautas $77,92 \%$ skysčio išeiga. Pirolizès produktu sudetis ir cheminès savybès taip pat buvo prognozuojamos modeliuojant ir gerai sutariamos su eksperimentiniais rezultatais. Tai parodè, kad panaudotos alyvos pirolizè gali labai gerai išgauti skystą produktą ir yra efektyvi perdirbimo technika.

Raktiniai žodžiai: pirolizè, modeliavimas, panaudota alyva, „Aspen Hysys“. 